\title{
MAGNESIUM-ALLOY DIE FORGINGS FOR AUTOMOTIVE APPLICATIONS
}

\author{
IZKOVKI IZ MAGNEZIJEVIH ZLITIN ZA AVTOMOBILSKO \\ INDUSTRIJO
}

\author{
Michal Madaj', Miroslav Greger'1, Vlastimil Karas² \\ ${ }^{1}$ VŠB-Technical University of Ostrava, Regional Materials Science and Technology Centre, 17. listopadu 15/2172, 70833 Ostrava-Poruba, \\ Czech Republic \\ ${ }^{2}$ KOVOLIT, a.s., Nádražní 344, 66442 Modřice, Czech Republic \\ michal.madaj@vsb.cz, vlastimil.karas@kovolit.cz
}

Prejem rokopisa - received: 2013-09-30; sprejem za objavo - accepted for publication: 2014-06-03

doi:10.17222/mit.2013.174

\begin{abstract}
The paper presents an investigation of the effect of process variables and material condition on the forgeability of magnesium wrought alloys of the Mg-Al-Zn group. The experimental work included the studies of forging capabilities of the alloys in open-die forging at hot- and warm-working temperatures. Forging tests were performed for the material in both the as-cast and as-worked conditions, for two variants of the work-piece geometry. Different variants of the work piece indicated fracturerelated problems in forging magnesium alloys in the warm-working temperature mode, which involved an interaction between the material composition and process variables, and the state of stress. By means of numerical calculations it was concluded that, in addition to the material condition, the favourable state of stress, provided by a closed die, could greatly improve the formability of magnesium alloys in the warm-working range.

Keywords: forging, magnesium alloys, automotive applications
\end{abstract}

Članek predstavlja preiskavo vplivov procesnih spremenljivk in materiala na kovnost magnezijevih zlitin iz skupine Mg-Al-Zn. Eksperimentalno delo je vključevalo študij sposobnosti za kovanje zlitin v odprtem orodju pri temperaturah vročega in toplega preoblikovanja. Preizkusi kovanja so bili izvršeni za material v litem stanju in za že predelan material za dve vrsti izkovkov z različno geometrijo. Različne variacije izkovkov so pokazale pri kovanju magnezijevih zlitin težavo z razpokami pri toplem preoblikovanju ter interakcijo med sestavo materiala, procesnimi spremenljivkami in stanjem napetosti. Z numeričnimi izračuni je bilo ugotovljeno, da dodatno k razmeram materiala lahko ugodno stanje napetosti, ki se ga doseže z zaprtim orodjem, močno izboljša preoblikovalnost magnezijevih zlitin v območju toplega preoblikovanja.

Ključne besede: kovanje, magnezijeve zlitine, uporaba v avtomobilski industriji

\section{INTRODUCTION}

The automotive industry, characterised by having the largest potential for development, is becoming an important user of magnesium materials. The use of magnesium in vehicles was, for decades, limited to the castings of complicated shapes for engines and wheels. Traditional die casting dominated for economic reasons. A possibility of using the components from magnesium materials including chassis and drives is now being considered. It turns out that it is suitable to replace the so-far used parts made of steel and aluminium with magnesium alloys. The use of magnesium alloys for the components of the chassis leads to high requirements for their strength, toughness and service life. Most of these properties are achieved by forging. The importance of using the forgings from magnesium alloys in passenger vehicles in comparison with the currently used die-cast castings is continuously increasing ${ }^{1}$. The use of magnesium alloys in cars depends on the price relation between aluminium and magnesium alloys. Table $\mathbf{1}$ compares the current economic possibilities of replacing aluminium alloys with magnesium alloys, as well as the price relations expected in the years to come.

Figure 1 shows that the main market for forged components is the automotive industry. The forging industry

Table 1: Price relations between the forgings made of aluminium and magnesium alloys ${ }^{1}$

Tabela 1: Primerjava cen izkovkov iz aluminija in magnezijevih zlitin ${ }^{1}$

\begin{tabular}{|l|c|c|c|c|c|c|}
\hline \multirow{2}{*}{$\begin{array}{c}\text { Price relation } \\
\text { aluminium - magnesium }\end{array}$} & \multicolumn{2}{c|}{ Aluminium } & \multicolumn{2}{c|}{ Magnesium - current price } & \multicolumn{2}{c|}{ Magnesium - target price } \\
\cline { 2 - 7 } & $€ / \mathrm{kg}$ & $€ / \mathrm{dm}^{3}$ & $€ / \mathrm{kg}$ & $€ / \mathrm{dm}^{3}$ & $€ / \mathrm{kg}$ & $€ / \mathrm{dm}^{3}$ \\
\hline Basic metal & 2.4 & 6.5 & 4.3 & 7.7 & 3.6 & 6.5 \\
\hline Initial blank & 0.7 & 1.9 & 2.9 to 4.3 & 5.2 to 7.7 & 1.4 to 2.1 & 2.5 to 3.7 \\
\hline Forging and finishing & $5-7$ & $14.3-19.8$ & $10-20$ & $18-36$ & $5-10$ & $9-18$ \\
\hline Total costs & $8-10$ & $23-28$ & $17-29$ & $31-51$ & $10-16$ & $1-28$ \\
\hline Comparison with Al alloys & $100 \%$ & $100 \%$ & $210-280 \%$ & $140-180 \%$ & $120-160 \%$ & $80-100 \%$ \\
\hline
\end{tabular}




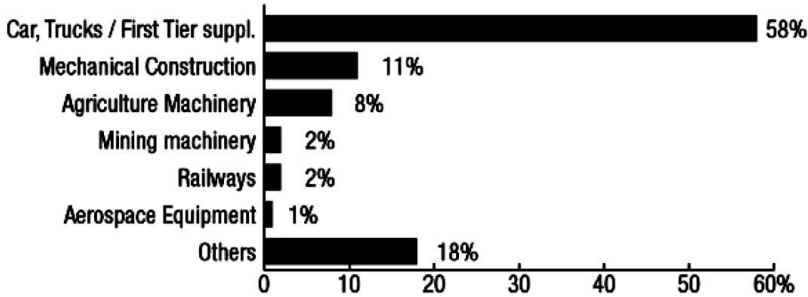

Figure 1: Customer profile of the European forging industry ${ }^{2}$ Slika 1: Profil porabnikov evropske industrije izkovkov ${ }^{2}$

is thus faced with some particular trends that relate to the developments within this sector ${ }^{2}$.

It is increasingly recognised that aluminium (with a density of $\left.2,700 \mathrm{~kg} / \mathrm{m}^{3}\right)$ and magnesium $\left(1,800 \mathrm{~kg} / \mathrm{m}^{3}\right)$ are attractive alternatives to steel $\left(7,800 \mathrm{~kg} / \mathrm{m}^{3}\right)$. Notably magnesium is the lightest available engineering metal, being by $75 \%$ lighter than steel and by $35 \%$ lighter than aluminium $^{3}$. To further specify this aspect, Figure 2 gives an overview of the intrinsic weight-saving potential for some magnesium wrought alloys in comparison with the aluminium reference alloy which is in use for forgings.

Figure 2 distinguishes between some distinct modes of loading, taking into account the relevant material properties: modulus of elasticity $E$, yield stress $Y S$ and density $\rho$ (for the other modes of loading, other design parameters apply). Although these data depend somewhat on the assumptions and the values of the specific property, this basic approach clearly demonstrates that benefits are anticipated for the strength-related and, in particular, for the bending-relevant parts, with a potential gain for magnesium of even $37 \%$ over aluminium ${ }^{3}$.

The mechanical properties of $\mathrm{Mg}$ can be substantially increased by alloying it with aluminium (up to $w=10$ $\%$ ), zinc (up to $w=6 \%$ ), manganese (up to $w=2.5 \%$ ) and zirconium (up to $w=1.5 \%$ ). Aluminium and zinc form a solid solution with magnesium. Intermetallic phases of types $\mathrm{Mg}_{17} \mathrm{Al}_{12}$ and $\mathrm{MgZn}_{2}$ are formed when

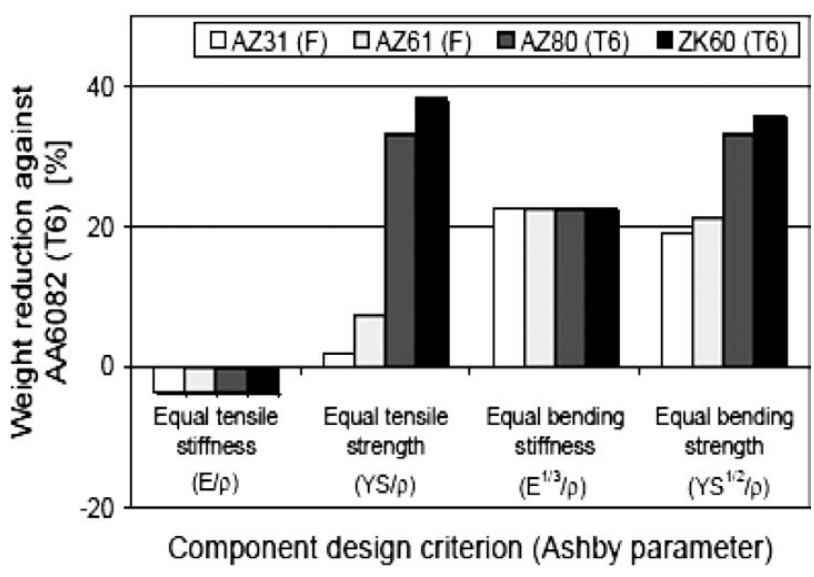

Figure 2: Mass-saving potential of magnesium over aluminium for some typical loading situations ${ }^{3}$

Slika 2: Možnost prihranka mase magnezija $\mathrm{v}$ primerjavi $\mathrm{z}$ aluminijem za nekatere značilne primere obremenitve ${ }^{3}$ their amounts are higher. In both cases the quantity of the alloying element increases the basic mechanical properties. Manganese and magnesium form a solid solution, $\alpha-\mathrm{Mg}$. The solubility of manganese in magnesium decreases with the decreasing temperature and the $\alpha$-Mn phase precipitates from the $\alpha-\mathrm{Mg}$ solid solution. An addition of manganese does not influence the achieved strength characteristics, but it favourably influences the resistance to corrosion. An increase in the level of the resistance to corrosion can be explained with the fact that a thin layer of $\mathrm{Mg}-\mathrm{Mn}$ oxides is formed on the surface. An addition of manganese decreases the effect of iron in magnesium. Manganese and iron form a compound of a high density, which settles at the bottom of the bath during the melting. Apart from the basic additions of these elements, an addition of tin is also used in magnesium alloys. Tin is soluble in magnesium at the temperature of $645{ }^{\circ} \mathrm{C}$ up to the amount of approximately $w=$ $10 \%$. Its solubility decreases with the temperature, with a simultaneous precipitation of the $\beta$ phase $\left(\mathrm{Mg}_{2} \mathrm{Sn}\right)$. Complex Mg-Al-Mn alloys alloyed additionally with $w=$ $5 \%$ of Sn have good hot formability. Silicon is insoluble in magnesium. They form an intermetallic phase of the $\mathrm{Mg}_{2} \mathrm{Si}$ type, which significantly strengthens the basic matrix ${ }^{4}$. Due to a significant increase in the brittleness, the amount of silicon in the alloys is under $w=0.3 \%$. As the alloying of magnesium alloys with zirconium refines the grains, the achieved level of mechanical properties increases and, at the same time, the resistance to corrosion decreases. The elements of rare-earth metals or thorium increase the refractoriness of magnesium alloys. Beryllium, in the amount of $w=0.005-0.012 \%$, decreases the oxidation of alloys during melting, casting and heat treatment ${ }^{5}$.

One of the limitations of using the formed magnesium alloys for the production of forged parts is their low formability. For this reason, most of these materials are processed by forming at elevated temperatures, which is reflected in their strength properties. A lower forging temperature increases the precision of the forged parts, but it greatly deteriorates their formability and the material factors - the grain size, the limited number of slip systems at low temperatures and the resistance of a metal to formation of cracks, which is one of the important factors of formability.

Magnesium and the majority of its alloys crystallise in a hexagonal system. This system is characterised by a reduced formability, which is caused by a small number of slip mechanisms. Slips of dislocations take place in selected crystallographic planes and directions, and they are controlled by three known laws. Up to the temperature of $220{ }^{\circ} \mathrm{C}$ the only slip plane in magnesium is in the basal plane (0001) and direction [1120]. At higher temperatures the slip begins in plane $(11 \overline{1} 0)$ in direction $[11 \overline{2} 0]$. These are the planes and directions in HCP lattices that are most densely occupied by atoms. The formability increases significantly with an increase in the 
slip systems. The values of the critical slip stress $\left(\tau_{\mathrm{kr}}\right)$ for pure magnesium are low. The value of the critical slip stress depends on the purity of the metal, the structure and thermodynamic conditions of deformation. The higher the purity of the metal, the lower is the magnitude of the critical slip stress. The impurities forming solid solutions with the basic metal increase $\tau_{\mathrm{kr}}$ more intensely than the impurities that are insoluble in the basic metal ${ }^{6}$. If a metal and admixture form a solid solution, then the value of the critical stress increases in dependence of the difference between the magnitudes of atoms of both metals, and the difference between the electrochemical properties of both metals. The admixture elements in magnesium interact with the dislocations, increasing the critical slip stress. The influence of the admixture elements on $\tau_{\mathrm{kr}}$ can be determined with the following equation:

$$
\tau_{\mathrm{kr}}=c^{n}
$$

where $c$ is the concentration of the admixture element and $n$ is the exponent ( $n \approx 0.5-0.66$ ).

The values of the critical slip stress decrease for the majority of metals with the increasing temperature. The influence of the temperature is not unequivocal in the case of magnesium and its alloys. Various slip planes can act at various temperatures. For example, at room temperature $\mathrm{Mg}$ alloys have only one system of slip planes. The number of active slip planes increases with an increase in the temperature, which is manifested with a rapid decrease in the slip stress. The yield strength of magnesium alloys can be approximately determined with the following equation:

$$
\sigma_{\mathrm{k}}=\frac{\tau_{\mathrm{kr}}}{m}
$$

where $m$ is the Schmid factor $\left(m_{\max } \approx 0.5\right)$.

Table 2 presents the basic parameters of the technical procedure of forging magnesium alloys, as well as their mechanical and technological properties.

The basic properties of magnesium alloys depend on the achieved structural state, which is a function of the chemical composition, applied deformation and heat treatment. Recrystallisation annealing is performed at the temperature of around $350{ }^{\circ} \mathrm{C}$. The recrystallisation of magnesium alloys strengthened by deformation starts in the temperature interval of $250-280{ }^{\circ} \mathrm{C}$. This temperature interval depends on the degree of strain hardening. Most of the magnesium alloys alloyed with manganese or aluminium are used in the heat-treated conditions, i.e., after quenching and aging. The achieved higher strength is connected with the changed solubility of the admixture elements - Al, $\mathrm{Zn}$ and $\mathrm{Zr}$ - in dependence of the temperature. The heating before quenching is selected in such a way that the segregated intermetallic phases of types $\mathrm{MgZn}_{2}, \mathrm{Mg}_{17} \mathrm{Al}_{12}, \mathrm{Mg}_{3} \mathrm{Al}_{2} \mathrm{Zn}_{2}$ are dissolved in a solid solution. A homogenous oversaturated solid solution is obtained after the quenching. During aging the strengthening phases precipitate. A characteristic property of magnesium alloys is a low rate of diffusion processes and that is why the processes of the phase transformation run very slowly. During the heating before quenching the dwell times of 4-24 h are applied. Artificial aging in magnesium alloys runs within the interval from 16-24 h. The selected magnesium alloys can also be quenched by cooling them in air from the finishforging temperature. The consequential aging performed directly from the finish-forging temperature is used without the inclusion of the previous solution annealing and quenching. The temperatures of the solution annealing of magnesium alloys vary from $380-420{ }^{\circ} \mathrm{C}$. Controlled aging is performed at the temperatures from $200-300{ }^{\circ} \mathrm{C}$. This procedure of heat treatment is marked as T1 and T4. To achieve the maximum level of strengthening, it is necessary to apply an aging temperature from 175-200 ${ }^{\circ} \mathrm{C}$. The changes in the properties achieved by aging are smaller for magnesium alloys in comparison with aluminium alloys. An increase in the strength properties after aging is not higher than 20-35\%. However, the plastic properties of alloys decrease after aging. For these reasons the most frequently used heat treatment is the homogenisation annealing. The mechanical properties are enhanced as a result of a more homogeneous structure. An application of natural aging does not practically lead to more significant changes in the strength properties $^{6,7}$.

\section{EXPERIMENTAL WORK}

We experimentally verified the forging procedure on the piston-rod and plate forgings, the final shapes of which are illustrated in Figure 3. Bars with the diameter of $30 \mathrm{~mm}$ and the length of $178 \mathrm{~mm}$ were used as initial blanks for the piston-rod forgings. The flat blank for the plate forging had the following dimensions: $130 \mathrm{~mm} \times$ $150 \mathrm{~mm} \times 13 \mathrm{~mm}$. The forged materials were made of magnesium alloys of types AZ31, AZ61 and AZ91. The

Table 2: Forging temperatures, mechanical and technological properties of the forgings from magnesium alloys ${ }^{6}$

Tabela 2: Temperature kovanja, mehanske in tehnološke lastnosti izkovkov iz magnezijevih zlitin ${ }^{6}$

\begin{tabular}{|c|c|c|c|c|c|c|c|}
\hline \multirow{2}{*}{ Alloy } & \multicolumn{2}{|c|}{ Forging temperatures $\left({ }^{\circ} \mathrm{C}\right)$} & \multicolumn{2}{c|}{ Mechanical properties } & \multicolumn{2}{c|}{ Technological properties } \\
\cline { 2 - 8 } & for forgings & for die forgings & YS/MPa & UTS/MPa & Elong. $\Delta l / \%$ & Weldability & $\begin{array}{c}\text { Resistance to } \\
\text { corrosion }\end{array}$ \\
\hline AZ31 & $290-345$ & $260-315$ & 195 & 260 & 9.0 & $\mathrm{O}$ & $\mathrm{G}$ \\
\hline AZ61 & $315-370$ & $290-345$ & 180 & 295 & 12.0 & $\mathrm{G}$ & $\mathrm{G}$ \\
\hline AZ91 & $300-385$ & $205-290$ & 250 & 345 & 5.0 & $\mathrm{G}$ & $\mathrm{G}$ \\
\hline
\end{tabular}

Note: O - outstanding, G - good 
(a)

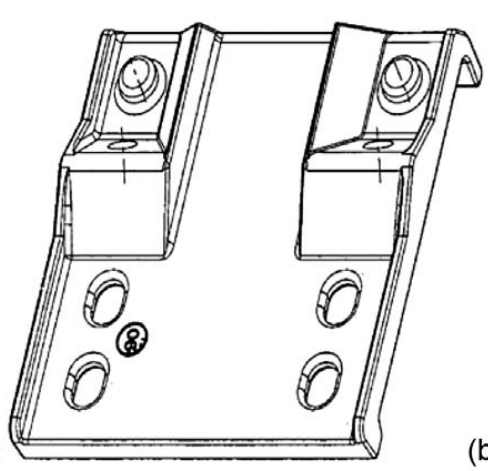

(b)

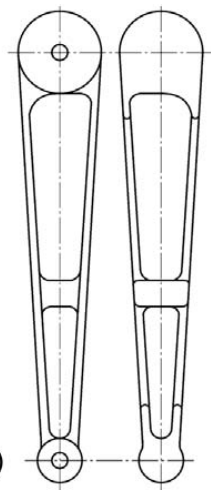

Figure 3: a) Shape of the flat-plate forging and b) shape of the piston-rod forging

Slika 3: a) Oblika izkovka plošče in b) oblika izkovka ojnice

Table 3: Chemical composition of magnesium alloys for forgings Tabela 3: Kemijska sestava magnezijevih zlitin za kovanje

\begin{tabular}{|c|c|c|c|c|c|c|c|}
\hline \multirow{2}{*}{ Alloy } & \multicolumn{7}{|c|}{ Amounts of alloying elements in mass fractions, $w / \%$} \\
\cline { 2 - 8 } & $\mathrm{Al}$ & $\mathrm{Zn}$ & $\mathrm{Mn}$ & $\mathrm{Si}$ & $\mathrm{Cu}$ & $\mathrm{Fe}$ & $\mathrm{Ni}$ \\
\hline \multirow{2}{*}{$\mathrm{AZ31}$} & $2.50-$ & $0.20-$ & $\geq$ & $\leq$ & $\leq$ & $\leq$ & $\leq$ \\
& 3.50 & 0.80 & 0.200 & 0.100 & 0.05 & 0.005 & 0.005 \\
\hline AZ61 & 6.76 & 0.38 & 0.13 & 0.05 & 0.006 & 0.011 & - \\
\hline AZ91 & 8.76 & 0.73 & 0.22 & 0.05 & 0.010 & 0.011 & - \\
\hline
\end{tabular}

Table 4: Initial parameters for forging the piston rods

Tabela 4: Začetni parametri pri kovanju ojnice

\begin{tabular}{|c|c|c|c|c|}
\hline Alloy & $\begin{array}{c}\text { Tempe- } \\
\text { rature } \\
\left({ }^{\circ} \mathrm{C}\right)\end{array}$ & $\begin{array}{c}\text { Mass of } \\
\text { the blank } \\
(\mathrm{g})\end{array}$ & $\begin{array}{c}\text { Dimensions and } \\
\text { shape of forgings } \\
\text { were satisfactory }(\%)\end{array}$ & Flow stress \\
\hline AZ31 & 350 & 30 & 100 & low \\
\hline AZ61 & 320 & 30 & 97 & medium \\
\hline AZ91 & 300 & 30 & 95 & high \\
\hline
\end{tabular}

chemical compositions of the forged alloys are presented in Table 3.

Forgings were used in the heat-treated as well as in the non-treated states. Before forming, the input blanks were subjected to homogenisation annealing at the temperatures of $380-420{ }^{\circ} \mathrm{C}$. The duration of annealing was $15 \mathrm{~h}$.

After the forging the samples were subjected to the heat treatment (recrystallisation annealing), which consisted of a gradual reheating of the forgings in the furnace at a rate of $20^{\circ} \mathrm{C}$ per minute up to a temperature of approximately $420{ }^{\circ} \mathrm{C}$. The forgings were left at this temperature for three hours and then cooled in water. Approximately four hours after the completion of the annealing the surfaces of the forgings were blasted with Cr-balls.

The forging of the piston-rod and plate forgings was performed in an open die on a hydraulic press MW PA 200. The samples were forged with a single strike at a temperature of $300-350{ }^{\circ} \mathrm{C}$ depending on the type of the alloy (Table 4). In the case of the piston-rod forging, the bleed was cut-off in the hot state, immediately after the completion of the forging.
The temperature of the die tool was approximately $150-170{ }^{\circ} \mathrm{C}$. The Acheson Dag 554/20 lubricant diluted with water at a ratio of $1: 20$ was used as a lubricating medium. The power of the stamping machine was set to $45 \%$ and its stroke to $220 \mathrm{~mm}$ (the lowest possible value on the machine for such forgings).

After the forging the test samples for a metallographic analysis of the structure were taken from the forgings. The piston-rod samples were cut along the axis of symmetry in order to examine the change in the structure at individual places of the cut. The sample preparation also included their grinding, polishing and subsequent etching.

The polishing was performed in two phases. In the first phase the samples were polished on a cloth with a soft nap using a polishing suspension based on $\mathrm{Al}_{2} \mathrm{O}_{3}$. However, after the completion of the first phase of the polishing, the sample surfaces still contained a large amount of scratches and it was, therefore, necessary to start the second phase of polishing on a very fine velvet cloth with short hair. Thus polished samples were cleaned with water, rinsed in alcohol and dried by warm air. The prepared surfaces were etched in $4 \% \mathrm{HNO}_{3}$ (Nital) in order to remove the deformed layer for its identification.

After the heat treatment, the test specimens for the determination of Brinell hardness were taken from the forgings. The hardness test was performed $10 \mathrm{~d}$ after the forging, prior to the heat treatment and also after the heat treatment. The load during the hardness test was $306.5 \mathrm{~N}$ and the diameter of the indenting ball was $2.5 \mathrm{~mm}$.

Three indents were made on each sample while keeping the distance between individual indents in accordance with the ISO 6506 standard recommending at least $5 \mathrm{~mm}$ in order to avoid the results to be influenced by strain hardening. The samples were subjected to a load for approximately 25 seconds.

\section{RESULTS AND DISCUSSIONS}

The deformation behaviour and development of the structures of six alloys and two shapes of the products were verified experimentally. All the forgings were forged without any problem and with respect to technology no problem occurred during the forging of magnesium alloys. After the forging the flow stress was assessed quantitatively (Table 5).

Table 5: Flow stress of the formed alloys

Tabela 5: Napetost tečenja preoblikovanih zlitin

\begin{tabular}{|c|c|}
\hline Material - shape & $\begin{array}{c}\text { Average residual } \\
\text { energy }(\mathrm{kN})\end{array}$ \\
\hline AZ31- piston rod & 5166 \\
\hline AZ61- piston rod & 4864 \\
\hline AZ91- piston rod & 4858 \\
\hline AZ31- plate & 4496 \\
\hline AZ61- plate & 4369 \\
\hline AZ91- plate & 4285 \\
\hline
\end{tabular}



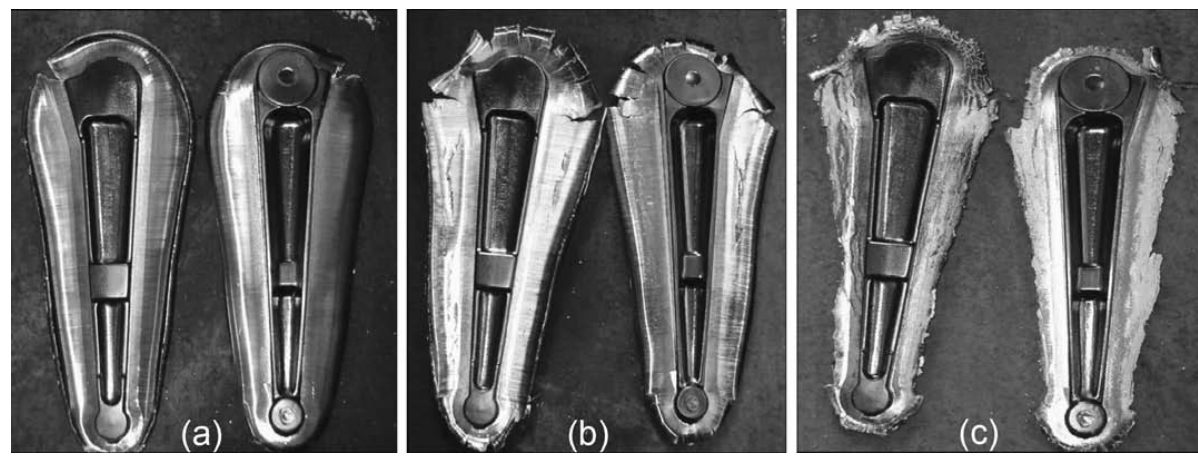

Figure 4: Shapes of the forgings from the magnesium alloys: a) AZ31, b) AZ61, c) AZ91 Slika 4: Videz izkovkov iz magnezijevih zlitin: a) AZ31, b) AZ61, c) AZ91

During the forging after a strike the energy was discharged onto the contact surfaces - it means that the forgings with the lowest residual energy had the highest flow stress. It follows from the obtained results that among the magnesium alloys the AZ91 alloy has the highest flow stress, followed progressively by AZ61 and AZ31. Some of the piston-rod forgings had a scratch on the larger diameter, which might have been related to the crack formation and such parts were investigated. The shapes of the forgings are shown in Figure 4.

For the preparation of the flat forging it was absolutely necessary to adapt the contact surfaces, which had to be parallel and smooth since any possible deep scratch could cause a formation of cracks. The shapes of the forgings are shown in Figure 5.

The metallographic investigation of the samples was performed in the initial state, after the heat treatment and, finally, after the forging and heat treatment. The analysis of the microstructure was focused on the formation of the cracks that were highlighted during the technological production of the forgings and the individual phenomena associated with the forming of magnesium alloys (dynamic recrystallisation, twinning, growth and shape of grains).

In the initial state, the microstructures of magnesium alloys AZ31, AZ61 and AZ91 contained the majority phase (a solid solution of aluminium in magnesium) and two types of the minority phase. The first type of the

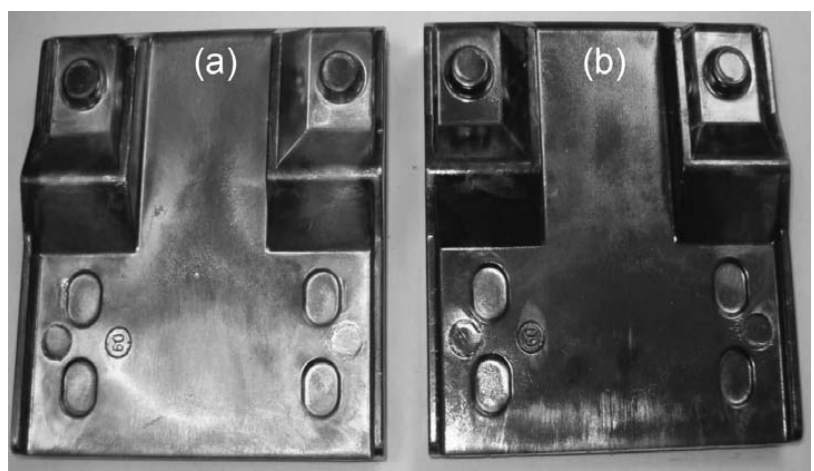

Figure 5: Shapes of the forgings from the magnesium alloys: a) AZ31, b) AZ61

Slika 5: Videz izkovkov iz magnezijevih zlitin: a) AZ31, b) AZ61

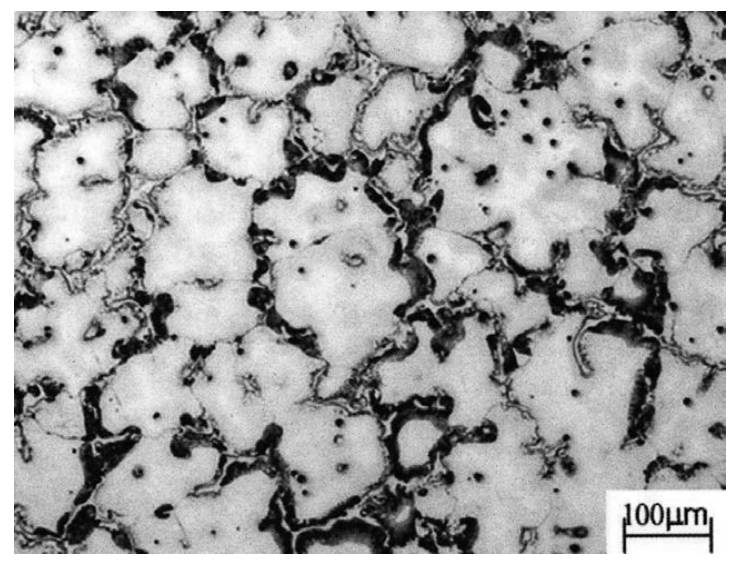

Figure 6: Microstructure of alloy AZ91 in the as-cast state, a crosssection

Slika 6: Strjevalna mikrostruktura zlitine AZ91; prečni prerez

minority phase consisted of relatively massive particles of $\mathrm{Mg}_{17} \mathrm{Al}_{12}$, while the second type consisted of fine, needle-like particles of the same phase present in the vicinity of the grain boundaries (Figure 6).

The objective of the homogenisation annealing was to remove the segregation heterogeneities of the admixture elements. During the homogenisation annealing the

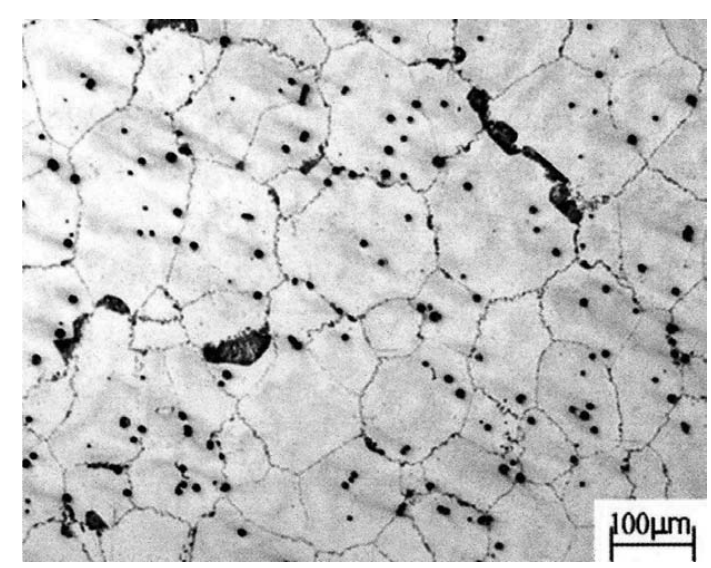

Figure 7: Microstructure of the AZ91 alloy after the homogenisation annealing, a cross-section

Slika 7: Mikrostruktura zlitine AZ91 po homogenizacijskem žarjenju; prečni prerez 

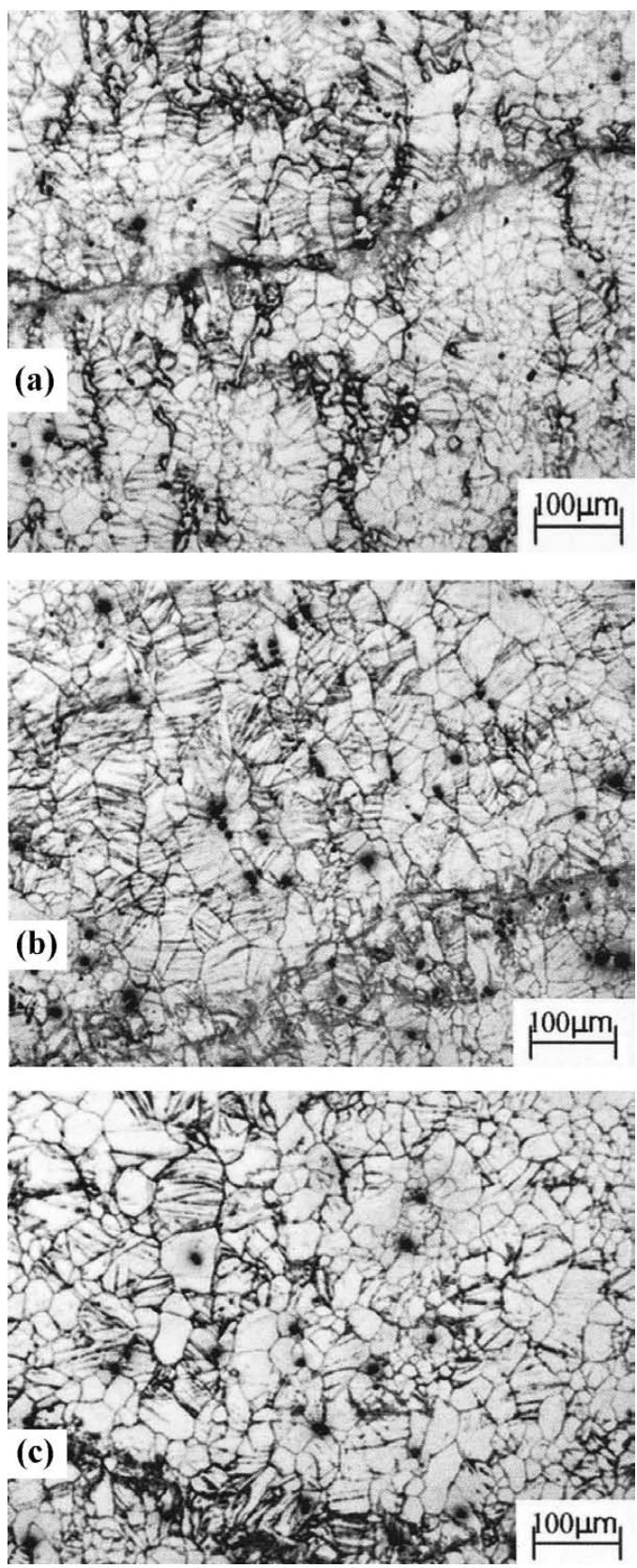

Figure 8: Microstructures of the alloys: a) AZ31, b) AZ61 and c) AZ91 after the forging, a cross-section

Slika 8: Mikrostrukture zlitin: a) AZ31, b) AZ61 in c) AZ91, po kovanju; prečni prerez

segregated phases on the grain boundaries dissolved in the basic matrix and the chemical composition of the alloy was more homogenous (Figure 7). This improved the formability and enhanced the level of mechanical properties.

The structures of the forged piston rods made of alloys AZ31 and AZ61 did not show any defects that could cause a subsequent failure of the components. The grains of both alloys were stretched in the direction of the intensive flow of the material, i.e., in the longitudinal direction of the forging. In alloy AZ61 a dynamic recry- stallisation took place, which started at the boundaries of the original grains, being supported by a sufficiently large number of precipitates of $\mathrm{Mg}_{17} \mathrm{Al}_{12}$ and by the created twins. The recrystallisation gradually expanded toward the centre of the basic grains. The piston rod made of alloy AZ91 had its central part without any significant failures; however, its peripheral parts were characterised by the cracks that penetrated deeper into the sample. In this alloy a dynamic recrystallisation on the grain boundaries took place, but there was insufficient time for its propagation into the entire volume (Figure 8).

With respect to the flat blank for plate forging, the best forging over the entire cross-section was achieved with the AZ31 alloy that showed no cracks. The AZ61 alloy contained no cracks in the central part of the component, but under the surface some cavities were formed, which could cause a failure of the given component during the subsequent use.

The most damaged microstructure was found for alloy AZ91, where cracks were present right under the surface in all the areas, penetrating deeper into the component and, in some cases, they appeared on the surface as well. It was evident from the metallographic investigation that the cracks were preferentially formed on the grain boundaries, particularly in the presence of phase $\mathrm{Mg}_{17} \mathrm{Al}_{12}$ or in the places where this phase was dissolved. The grains of all the forged alloys were considerably stretched in the direction of the bleed groove and in alloy AZ91 they led to a formation of a crack over the entire component.

After the annealing, a complete recrystallisation of the grains occurred in the sample made of alloy AZ91. The grains contained acicular particles, spread over the entire grains. In alloy AZ61, the recrystallised grains were present only on the borders of the original grains, but they did not spread throughout the entire volume. The chemical composition, i.e., the amount of aluminium, had a great influence on these processes. The secondary phases, and zinc- and aluminium-based

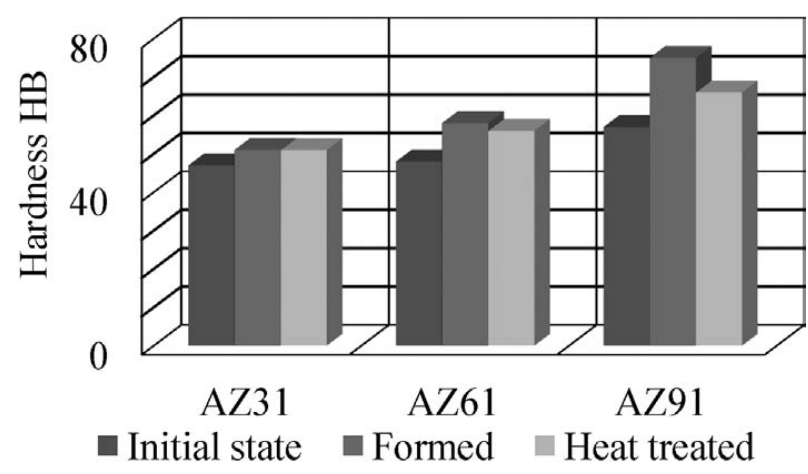

Figure 9: Hardness values of the piston-rod forgings in the initial state, after the forming and after the heat treatment

Slika 9: Trdota izkovka ojnice v začetnem stanju, po kovanju in po toplotni obdelavi 


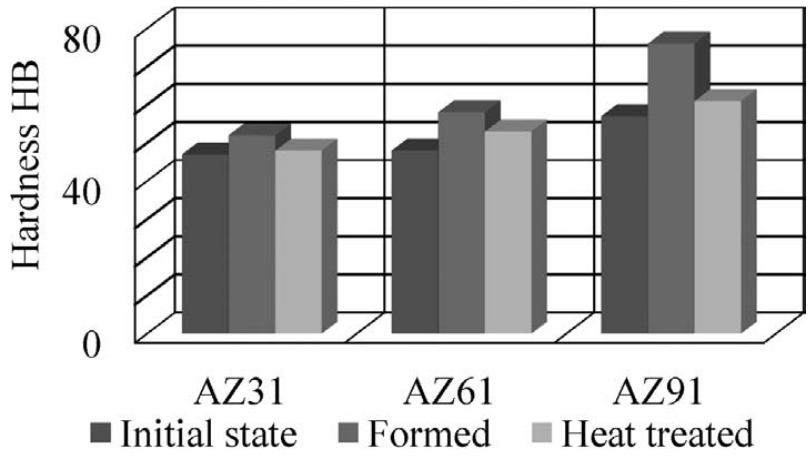

Figure 10: Hardness values of the plate forgings in the initial state, after the forming and after the heat treatment

Slika 10: Trdota izkovka plošče v začetnem stanju, po kovanju in po toplotni obdelavi

precipitates dissolved during the heat treatment in the basic matrix.

The mechanical properties of the forgings and their evolution in dependence of the heat treatment were verified with a hardness test. For all the investigated magnesium alloys in the initial state, the Brinell hardness values were measured after the forming and after the heat treatment, and they were averaged for individual alloys. The resulting hardness values are represented in Figures 9 and $\mathbf{1 0}$.

It follows from the results of the hardness tests that the heat treatment and forming had considerable influences on the hardness of magnesium alloys. The aluminium amount in the material is another factor, influencing the hardness. The material hardness decreases with the decreasing aluminium amount in the material (Table 3, Figures 9 and 10). During the forming the hardness of alloy AZ91 increased considerably - even by 19 HB. The hardness of alloy AZ61 increased by $10 \mathrm{HB}$. The weakest influence of the forming on the hardness value was found for alloy AZ31. After the heat treatment the hardness of alloy AZ91 dropped considerably, which was caused by the recrystallisation, taking place during the heat treatment. The heat treatment had no significant impact on the resulting hardness of alloys AZ31 and AZ61.

\section{CONCLUSIONS}

The deformation behaviour of alloys AZ31, AZ61 and AZ91 during die forging was experimentally verified. The influences of the forging technology and homogenisation annealing on the structures and properties of the forgings were compared. The influences of the heat treatment and the forming temperature on the final structure and mechanical properties were evaluated. It follows from the obtained results that the aluminium amount in the material as well as the heat treatment and forming had considerable influences on the hardness of the magnesium alloys. The initial structures used in the tests were in the as-cast form, which probably caused the formation of cracks in the alloys with higher aluminium amounts (AZ61, AZ91).

The results confirmed the suitability of applying heat treatment before forging. This procedure enabled us to obtain the forgings with a more homogeneous structure. After the application of forming some micro-cracks and voids were detected in the magnesium alloys of AZ61 and AZ91. The cracks were located just under the surface and they penetrated deeper into the material. In alloy AZ91 the micro-cracks were formed throughout the entire volume and the initiations of these micro-cracks were preferentially on the grain boundaries, mainly in the area of particles $\mathrm{Mg}_{17} \mathrm{Al}_{12}$. From the structural point of view, alloy AZ31, in which no structural defects were detected, was found satisfactory. The highest strength and hardness were obtained with alloy AZ91. It follows from the obtained results that with the increasing aluminium amount the hardness of forged magnesium alloys increases as well.

\section{Acknowledgement}

This paper was created within project No. CZ.1.05/ 2.1.00/01.0040 "Regional Materials Science and Technology Centre" within the frame of operational programme "Research and Development for Innovations" financed by the Structural Funds and the state budget of the Czech Republic.

\section{REFERENCES}

${ }^{1}$ R. Matsumoto, K. Osakada, Development of warm forging method for magnesium alloy, Materials Transactions, 45 (2004) 9, 2838-2844, doi:10.2320/matertrans.45.2838

${ }^{2}$ R. Asakawa, K. Hirukawa, Technology for manufacturing magnesium alloy components with excellent heat resistance, Kobelco technology review, 31 (2013), 76-81

${ }^{3}$ B. Płonka, M. L. Grega, K. Remsak et al., Die forging of highstrength magnesium alloys - the structure and mechanical properties in different heat treatment conditions, Archives of Metallurgy and Materials, 58 (2013) 1, 127-132, doi:10. 2478/v10172-012-0162-9

${ }^{4}$ M. Greger, L. Čížek, I. Juřička et al., Possibilities of mechanical properties and microstructure improvement of magnesium alloys, Archives of Materials Science and Engineering, 28 (2007) 2, 83-90

${ }^{5}$ M. Greger, M. Widomská, V. Karas, Properties of forging from magnesium alloys and their use in industry, Conference proceedings, Metal 2012, Ostrava, 2012, 440-445

${ }^{6}$ M. Greger, M. Widomská, Structural characteristics of magnesium alloys along the equal channel angular pressing, Advances in Engineering Plasticity and its Applications, Shanghai Jiaong University, Shanghai, 2004, 1083-1088, doi:10.4028/www.scientific.net/KEM. 274-276.1083

${ }^{7}$ D. Kobold, T. Pepelnjak, G. Gantar et al., Analysis of deformation characteristics of magnesium AZ80 wrought alloy under hot conditions, Journal of Mechanical Engineering, 56 (2010) 12, 823-832 